\title{
IMPORTANCE OF PICOPHYTOPLANKTON IN AQUATIC ECOSYSTEM
}

\author{
Hesham M. Shafik ${ }^{1}$ And Helga Leitold ${ }^{2}$ \\ 1-Botany Department, Faculty of Science, Port Said University, \\ Port Said, Egypt \\ 2-Institute of Environmental Engineering, University of Pannonia, Veszprém, \\ Hungary
}

\begin{abstract}
Since the rediscovery of picophytoplankton (PPP) in $1978-1979$, the information and method of studying of these living organisms have improving quickly. This review collects the most important methods for studding these tiny planktonic which play a significant role in all aquatic ecosystems. In addition to, give an over view on the results obtained on the contributions, abundant and role of these groups in different habitats and they correlation with physical, chemical and environmental parameters, such as temperature, light intensity and quality, salinity, $\mathrm{pH}$, trophic state, and grazing. The development of gene sequencing, the molecular approach and phylogenetic analysis give an advanced direction to taxonomy of PPP and their relation and interactions to environmental factor, therefore the review shows the new results of this topic.

Abbreviations: APC, allophycocyanin; Chl, chlorophyll; FALS, Forward Angle Light Scatter; FDA, fluorescein diacetate; FITC. Fluorescin isothiocyanate; FSC, forward scatter; OPA, optical plankton analyzer; Orange FL, Orange fluorescence Scatter; PC, phycocyanin; PE, phycoerythrin; PMT, photomultiplier tube; PPP, picophytoplankton; Red FL, red fluorescence; SSC, side scatter; UV, ultraviolt.
\end{abstract}

\section{Introduction}

In general, the picophytoplankton (PPP) fraction threshold varied from < 1 to $<3 \mu \mathrm{m}$ among the various studied. The smallest $(0,5-2,0 \mu \mathrm{m})$ picophytoplankton (photoautotrophic, prokaryotic and eukaryotic phytoplankters) were overlooked in earlier studies because the conventional Utermöhl settling technique for counting phytoplankton (Utermöhl, 1958) is inappropriate for such small cells. Single and/or colonial pico-sized cells settle too slowly and often indistinguishable from the more numerous heterotrophic bacteria. Since piocphytoplankton defined according to Sieburth et al. (1978), has been recognized as an important component within the pelagic communities of both freshwater and marine environments. Waterbury et al. (1979) and Johnson and Sieburth (1979) established that small coccoid cyanobacteria (Synechococcus spp.) make a substantial contribution to primary productivity throughout the world ocean. Since the late 1970s, considerably interest has focused on understanding the occurrence, dynamics, production and ecology of these ubiquitous 
microorganisms. Previous work in the oceans led to the conclusion that particles in the size class $<3 \mu \mathrm{m}$ are fragments of larger cells and metabolically inert. Numerous investigations have been carried on quantify the dynamics of PPP (Takahashi et al., 1985; Iturriaga and Marra, 1988; Hawley and Whitton, 1991; Vörös et al.,1991). It is established that PPP can provide an essential contribution to carbon fixation ranging from 1 to $90 \%$ of total primary production in marine and 16 to $70 \%$ in freshwater environments (Stockner, 1988). Stockner (1988) described a chlorophyll biomass contribution of algal piocphytoplankton to total phytoplankton chlorophyll ranging between 6 and $43 \%$ in marine and freshwater ecosystems. According to the latest studies the picoplankton are the most abundant primary producers in tropical and sub tropical waters in the world.

Before the discovery of chroococoid cyanoprokaryotes ubiquity in the oceans, there were only incidental reports of phototrophic picoplankters in both marine and freshwater ecosystems. Despite the PPP the most primary producers in the world oceans, their contribution to oceanic biomass and productivity has been explicitly recognized from about two decades ago, since the application of epifluorescence microscopical techniques (Caron et al.,1982) and flow cytometric instrumentation to oceanographic studies (Yentsch et al., 1983). Since 1982, the number of reported algal picoplankton occurrences has risen sharply.

\section{Materials and methods}

Generally, biomass as chlorophyll-a (Chl a) $\mu \mathrm{g}^{-1}$ and/or production $\mu \mathrm{g} \mathrm{C}$ $\mathrm{l}^{-1} \mathrm{~d}^{-1}$ used for the determination of picophytoplankton.

\section{Size fractionation and Separation methods}

The mean used method is the differential filtration that separate a phytoplankton sample to three size classes, micro $(200-20 \mu \mathrm{m})$, nano $(20-2$ $\mu \mathrm{m})$, and pico $(<2 \mu \mathrm{m})$ by gently vacuum pressure $(<5 \mathrm{~cm} \mathrm{Hg}$ or $200 \mathrm{mbar})$ through serial different pore size filters. For total chlorophyll content or total primary production a $0.2 \mu \mathrm{m}$ pore size filter is used. For the determinations of fraction $>2.0 \mu \mathrm{m}$ filters of $0.2 \mu \mathrm{m}$ is used then the filtrate obtained by this filtration step refilters through a $0.2 \mu \mathrm{m}$ pore size filter in order to determine the parameters of the size class of 0.2-2.0 $\mu \mathrm{m}$ (Steitz and Velimirove, 1999; Froneman et al., 2001). The main problem of size fractionation method is filter clogging during filtration; this problem has not been adequately addressed.

There are other methods such as temperature stratification and flotation that reported by Ambrožová (2001).

\section{Flow-cytometry}

Flow cytometric analysis of picoplankton was performed as described elsewhere (Vaulot and Marie, 1999; Collier, 2000). It measure light scattering 
and fluorescence characteristics from individual particles in a fluid stream as they cross one or more light beams at rates of up to thousands of events per second. Flow cytometrically detectable optical signals may arise naturally from algae, reflecting cell size, structure, and endogenous pigmentation, or may be generated by fluorescent stains that presence of otherwise undetected cellular constituents. Ultimately, the detection of molecular probes by flow cytometry may allow single cell taxonomic and physiological in formation to be garnered variety algae, both in culture and in nature. Fig. 1 shows a schematic diagram of the optical components of a fourcolor FACS-Calibur flow cytometer.

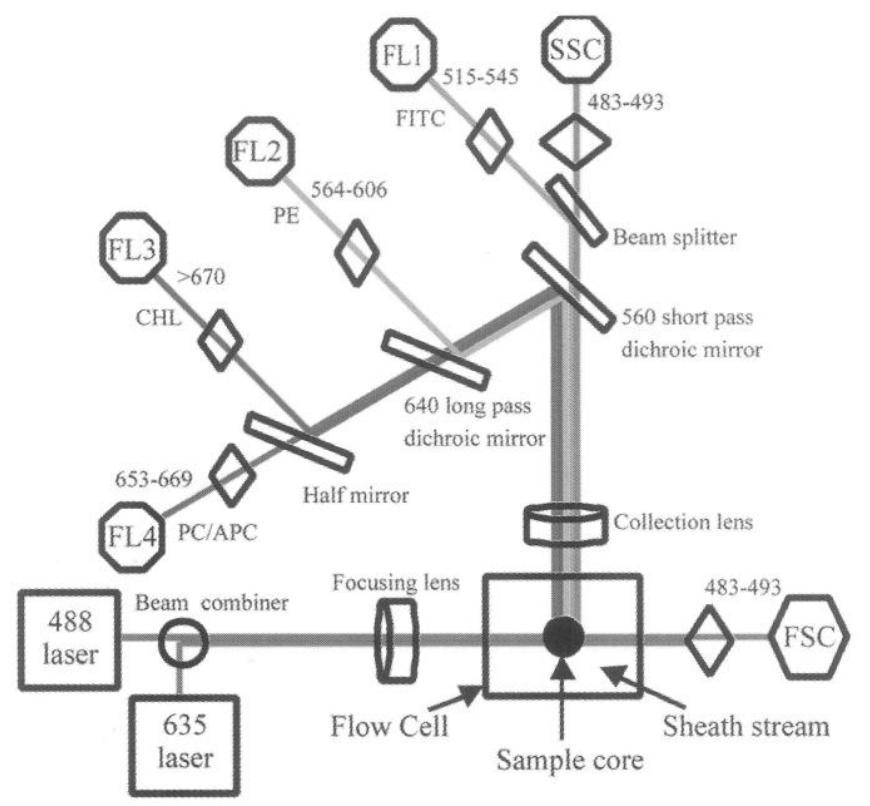

Figure (1): Schematic diagram of the optical components of a four-color FACSCalibur flow-cytometer. (Original from Collier, 2000).

The sample stream is flowing upward out of the plane of the page and the cylindrical sample core is centered within a rectangular sheath in the flow cell. Light form the blue argon $(488 \mathrm{~nm})$ and red diode $(635 \mathrm{~nm})$ lasers is focused by a common lens, but thew red laser intersects the sample stream before (below in this diagram, by $\sim 100 \mu \mathrm{m}$ and $19 \mu \mathrm{s}$, respectively) the blue. To compensate for this arrangement, the FL4 detector has a time delay incorporated into its signal processing electronics so that it reports fluorescence excited by the red laser at the same time that all other detectors respond to the same cell crossing the blue laser beams and sample core are not drawn to scale; the laser beams will actually be focused to elliptical spots $(22 \times 66 \mu \mathrm{m}$ for the blue and $15 \times 61 \mu \mathrm{m}$ for the red) 
oriented so that the sample crosses the short axis while the ensures even illumination across the sample core. The velocity is $6 \mathrm{~m} \mathrm{~s}^{-1}$, so each cell spends $4 \mu$ s crossing each leaser beam. At "low" flow rate, the sample runs at $\mu 1 \mathrm{~min}^{-1}$ in an $11 \mu \mathrm{m}$ diameter core, whereas at "high" flow rate the sample runs at $60 \mu 1 \mathrm{~min}^{-1}$ in a $56 \mu \mathrm{m}$ diameter core. The photodiode (hexagon) detecting the low-angle light scatter (FSC) is preceded by an optical filter (diamond) that removes any light other than the blue excitation. A collection lens oriented at $90^{\circ}$ to both the laser beams and sample flow directs light of any wavelength into a system of mirrors and filters positioned in front of the five photomultiplier tubes (PMTs, octagons). A $560 \mathrm{~nm}$ short pass dichroic mirror sends blue and green light toward two of the PMTs and then a beam splitter sends part of that signal through a blue (483 to 493 $\mathrm{nm}$ ) filter in the side scatter (SSC) detector while directing the rest of it through a green ( 515 to $545 \mathrm{~nm}$ ) filter of the FL1 detector (designed for FITC fluorescence). Light greater than $560 \mathrm{~nm}$ in the wavelength is directed to a $640 \mathrm{~nm}$ long pass dichroic mirror, where yellow/orange light is deflected through a filter (564 to 606 $\mathrm{nm})$ to the FL2 detector (designed for PE fluorescence). Light than $640 \mathrm{~nm}$ in wavelength passes through to a half mirror, where part of it is deflected through a $670 \mathrm{~nm}$ long pass filter to FL3 (designed for chl fluorescence) and the rest is passed through a red (653 to 669nm) filter to FL4 (designed for PC and APC fluorescence excited by red laser).

The sample treated with glutaraldehyde for $10 \mathrm{~min}(0.1 \%$ final concentration), and store in liquid nitrogen (Vaulot et al., 1989) till analysis, the sample thaw in water bath at $37^{\circ} \mathrm{C}$ just prior to cytometric analysis, then count immediately on the flow cytometer (Crosbie and Furnas, 2001).

Collier (2000) showed the flow cytometric signatures of freshwater phytoplankton from Lake George and Hudson River. Sample were preserved by fixation in $0.25 \%$ glutaraldehyde and freezing at $-80^{\circ} \mathrm{C}$ until analysed on the Rensselaer FACS-Calibur for $5 \mathrm{~min}$ at a flow rate of $12 \mu \mathrm{L} \mathrm{min}{ }^{-1}$. Each dot represents one signal (one cell) detected by FACS-Calibur optical system (Fig. 2).

Cavender-Bares et al. (1999) indicated the characters of phytoplankton community in terms of autofluorescence per cell, which is related to pigment concentration and Forward Angle Light Scatter (FALS) per cell, which is correlated with cell size. Chlorophyll or red fluorescence (Red FL) signals pass first through a $488 \mathrm{~nm}$ long pass filter, then reflect by a $630 \mathrm{~nm}$ short-pass dichroic filter and finally pass through a $680 \mathrm{~nm}$ band-pass filter (40nm bandwidth).

It is able to differentiate five separate groups of photosynthetic cells based on their distinct florescence and light scatter signals as represented in Fig. 3 (Cavender-Bares et al., 1999). The two cyanoprokaryotes Prochlorococcus and Synechococcous are easily differentiated from each other since only Synechococcous exhibits Orange fluorescence (Orange FL), phycoerythrin or 
orange fluorescence signals passed through the $360 \mathrm{~nm}$ short-pass dichroic and also through a $515 \mathrm{~nm}$ long-pass filter. Both cyanoprokaryotes have relatively low Forward Angle Light Scatter (FALS) signals per cell, which is correlated with cell size and separates them from the ultra and nano-plankton. The smallest ultraplankton are also distinguishable from Synechococcous because of their lack of Orange FL. The ultra and nano-phytoplankton are identified based on their size and fluorescence characteristics (Zettler $\boldsymbol{e t}$ al., 1996), and pennate diatoms can be identified because they scatter less light than would be expected for their size because of their long, slender shape (Zettler et al., 1996). For these measurements fluorescence and light scatter values must be reported relative to the value of a calibration microspheres that added to each sample (e.g. Polysciences 0.474 and $2.02 \mu \mathrm{m}$ ). For more details see Cavender-Bares et al. (1999).
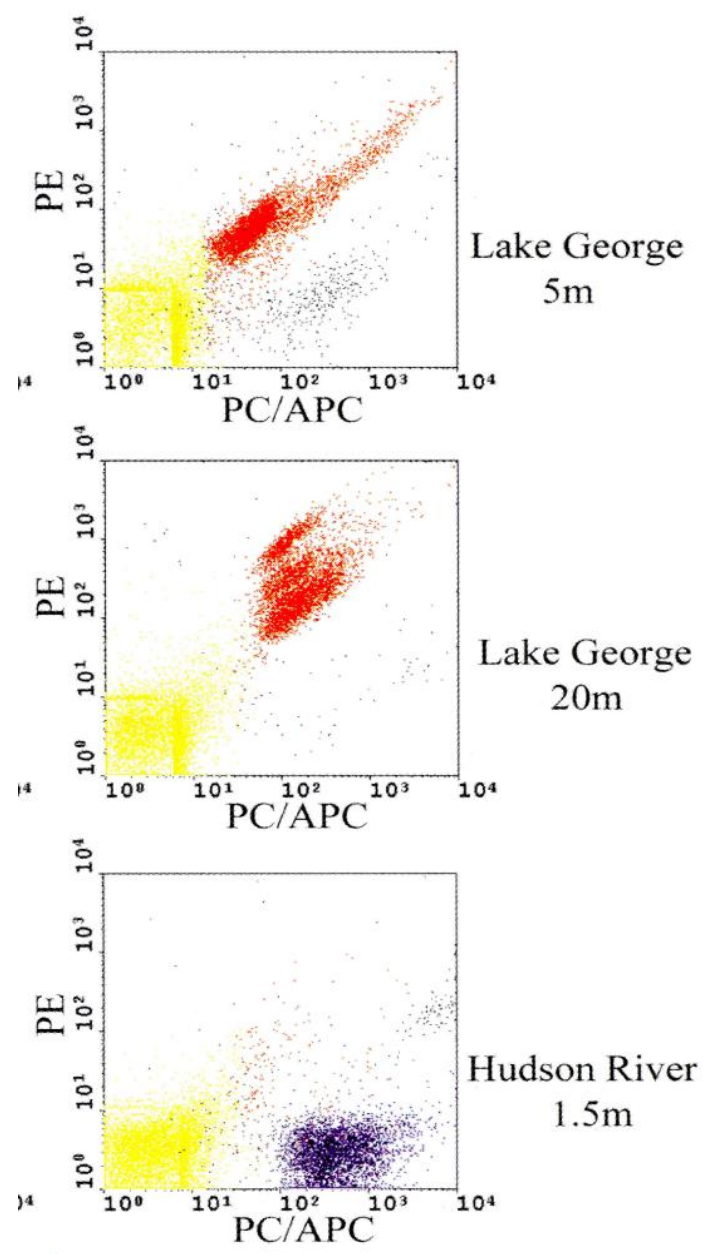

Figure (2): Shows PC/APC fluorescence (FL4) versus PE fluorescence (FL2).

The samples are collected from two depths of 5 and $20 \mathrm{~m}$ from Lake George and one depth $(1.5 \mathrm{~m})$ from Hudson River. The signals colored red have been confirmed by sorting and epifluorescence microscopy to represent PEcontaining unicellular cyanoprokaryotes (red colored). In the third panel blue colored indicate the PC-rich cyanoprokaryotes. The population appears to consist of a main group plus a long tail of signals that may represent colonial forms.

The signals colored black are probably eukaryotic picophytoplankton (PPP). The PE-rich cyanoprokaryotes also dominate the deeper sample. The yellow color shows the optical and electronic noise and real events of the flow cytometer (Modified after Collier, 2000). 
Figure (3): (A)

Flow

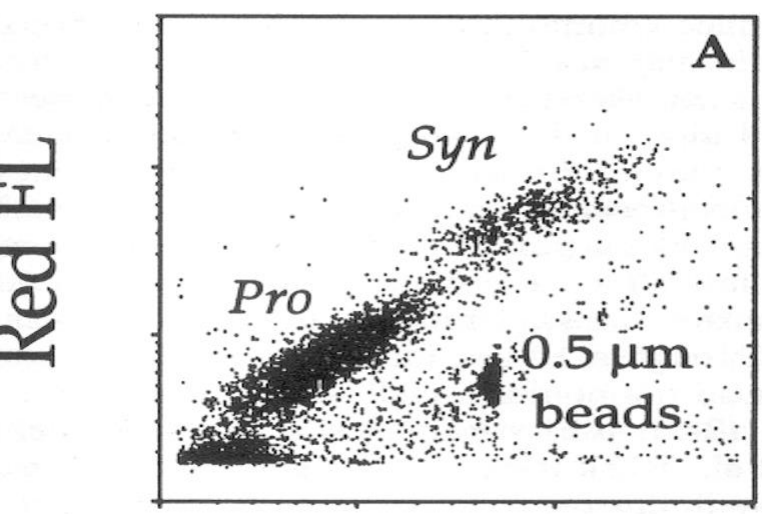

cytometric

scattergram of

Prochlorococcus

and

Synechococcus,

with Red FL

plotted against

FALS. (B) Orange

FL vs. FALS

scattergram

showing how

Synechococcus are separated from

Prochlorococcus,

since the latter do not exhibit Orange

FL.

(C)

Scattergram

showing the larger

cells in the ultra-

and nano-

plankton and

pennate diatoms

groups. Each dot

denotes an

individual cell.

Calibration

microspheres

(beads) of different

sizes were added to

each sample as

internal standard:

0.47 $\mu \mathrm{mfor} \quad$ A.B;

and $2.02 \mu \mathrm{m}$

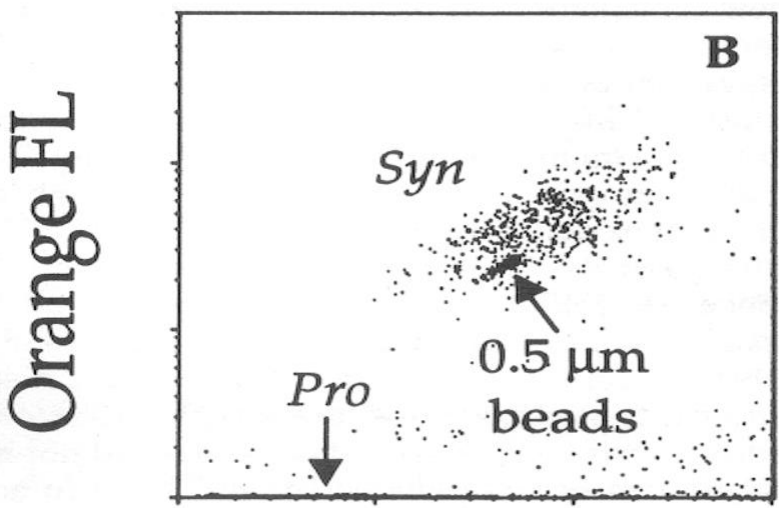

circled in $\mathbf{C}$.

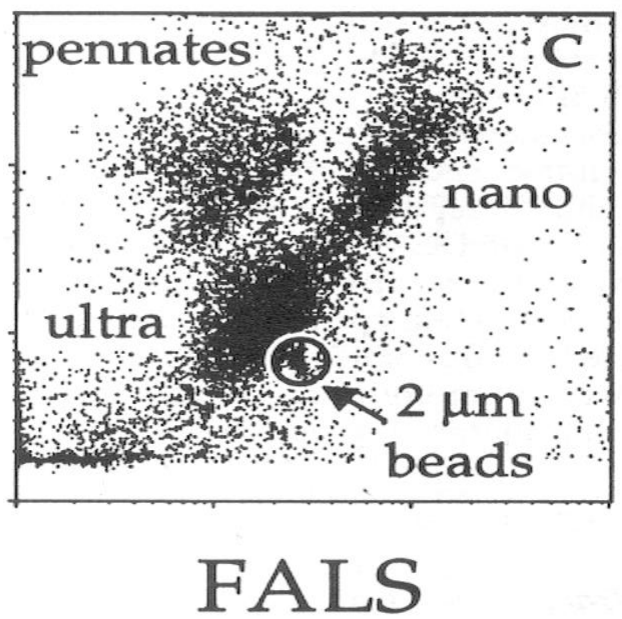




\section{Fluorescence}

The abundance of picophytoplankton's (eu- and/or prokaryotes) is determined using epifluorescence microscopy. Freshly collected sample of $0.5 \mathrm{ml}-$ 21 , according to the abundance of cells, is filtered through black polycarbonate filters of $0.4 \mu \mathrm{m}$ pore size. It is possible to preserve the pre-filtered samples with glutaraldehyde and formaldehyde (50:50, 1\%) (Caroppo, 2000).

After filtration the filters embedded into glycerol and counted under an epifluorescence microscope at 1250x magnification, using blue $(450-490 \mathrm{~nm}$; cutoff filter $515 \mathrm{~nm}$ ) excitation light. At this excitation the eukaryotic algae and the phycocyanin rich cyanoprokaryotes show red-fluorescence. While the cyanoprokaryotes rich in phycoerthrin show yellow-orange fluorescence using green excitation filter (515-650; cut-off filter $580 \mathrm{~nm}$ ) (Waterbury et al., 1986; Vörös et al., 2000).

\section{Studying of picophytoplankton in cultures}

Culture techniques are very useful methods to study the characteristic of picophytoplankton. The most used methods are batch cultures (Callieri et al., 1996), continuous culture of pure strain (Mostala et al., 1996), competitive experiments (Shafik, 1996), and mesocosm experiments (Agawin et al., 2000).

\section{Sequencing and phylogenetic analysis}

I give here an example for a method for studying the sequences of $18 \mathrm{~S}$ rRNA (Moon-van der Staay et al. 2000, 2001). Plasmid DNA containing amplified 18S rRNA genes from environmental samples purified with a flexiPrep Kit. 18S rRNA genes sequenced using a VISTRA automated sequencer (Aaersham). Sequencing primers including two plasmid primers and those specific for conserved regions of the 18S rRNA genes were 5' end labeled using the Texas Red labeling kit (Amersham). Both strands of the 18S rRNA genes are sequences. Sequences check from chimeric gene artifacts with Ribosomal RNA Database Project program CHECK-CHIMERA (Maidak et al., 1994). Nucleotide sequences are aligned with CLUSTALW (Thompson $\boldsymbol{e t}$ al., 1994) and adjusted manually based on primary and secondary structure consideration. The percentage of similarities between sequences is computed with CLUSTALW, excluding the positions with gaps. Only 1.742 positions considered to be unambiguously aligned are considered for phylogenetic analysis. Distance analysis (Neighbor-joining) and bootstrap analysis were performed using the PHYLIP program (Felsentein, 1993). The distance matrix of aligned sequences are generated using the program DNADIST by the use of the kimura 2-parameter model (Kimura, 1980) with a transition/transversion ratio of 2.0. The result of the phylogenic analysis is shown in Fig. 11. 


\section{Classification and occurrence of picoplankton}

There are two major groups of picophytoplankton divisible by cellular structure: prokaryotic (cyanobacteria and prochlorophytes) and eukaryotic (Stockner and Atina, 1986; Chisholm et al., 1988; Stockner, 1988; Stockner, 1991). The most attention has been devoted to the prokaryotic component, which comprises mainly two genera: Synechococcus (Johnson and Sieburth, 1979; Waterbury et al., 1979) and Prochlorococcus (Chisholm et al., 1992). In contrast, the eukaryotic picophytoplankton is much more diverse and apparently composed of organisms that belong to several algal divisions, including the Heretokonta, Chlorophyta, Prasinophyta, and Haptophyta (Potter et al., 1997). Within these algal lineage's, many new taxa, at the genus, order, or even class level have been described from picoplankton in last ten years. For example, Andersen et al. (1993) erected a new class, the Pelagophyceae Andersen and Saunders (Heteroknta), on the basis of a new picoplanktonic species, Pelagomons calceolata Andersen et Saunders. Saunders et al. (1997) added a new order, Sarcinochrysidales in this new class. The new order included Hargaves et Sieburth, that is responsible for brown tides in coastal waters (De Yoe et al., 1995). Latter, Guillou et al. (1999) represented a new class (Holidophyceae, Heterokonta) including a new genus, Bolidomonas with two species Bolidomonas pacifica and Bolidomonas mediterranea. The recognition of cyanoprokaryote picoplankton was facilitated by the application of epifluorescence microscopy adapted from its initial development for the enumeration of heterotrophic bacteria (Hobbie et al., 1977). No fluorochrome stains are necessary for their enumeration because each cyanoprokaryote picoplankter has a unique auto-fluorescent spectral signature, usually distinguishable from eukaryotic picoplankton. However, some phycocyanin-rich cyanoprokaryote may not be visually distinguishable easily from eukaryotic cells. Using epifluorescence technique pico-sized algae were found in all water samples collected from shallow Hungarian and deep Italian lakes (more than 30 different

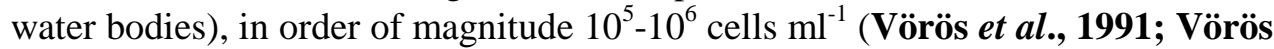
et al., 1998a). In respect to the chemical composition and total salt concentration of their water, most of them were characterised by the dominance of calcium-, magnesium- and hydrocarbonate-ions, however some of them had unique chemistry, they were representatives of alkaline (soda) lakes. The characteristically dominant organisms of picoplankton were, in all waters investigated, cyanobacteria of spherical (Fig. 4) and less frequently of ovoid or rod shape. They occurred either individually or in microcolonies of 4-40 cells and exhibited red or yellow-orange autofluorescence (cells exhibiting yellow-orange autofluorescence are rich in phycoerythrin while phycocyanin rich cells show red autofluorescence). Eukaryotic picoplankton were detected in most of the investigated lakes but their contribution to the total picoplankton abundance was 
negligible. Eukaryotes in size fraction $0.2-5 \mu \mathrm{m}$ from the aphotic zone (250$3000 \mathrm{~m}$ deep) are recorded in the Antarctic polar front at average temperature around $2{ }^{\circ} \mathrm{C}$ poor nutrient concentration and absence of light (Lopez-Garcia, 2001). Finally, Ambrožová (2001) recorded a picophytoplankton (Synechococcus capitatus) that grow and bloom in oligotrophic water, which used as source for drinking waters (Janov Reservoir, Czeck Republic).

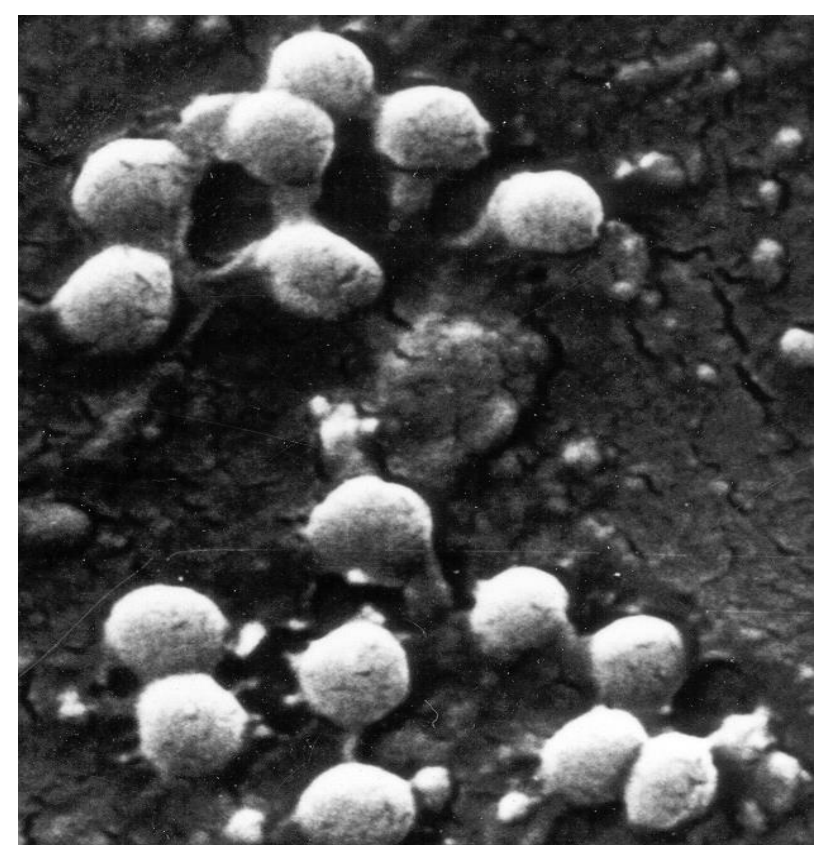

Fig. 4 Scanning electron micrograph of coccoid picocyanoplankton found in many aquatic habitats (cell size $1 \mu \mathrm{m}$ ).

Abundance and contribution of picoplankton in different tropic status, salinity, temperature, light and depth

Vörös and Padisák (1991) suggested that chlorophyll-a is the best descriptive and general parameter to indicate the trophic state. Chlorophyll-a is strictly related to the algal biomass, therefore a range going from 0,2 to $390 \mu \mathrm{g}^{-1}$ chlorophyll-a can be easily recognised as a trophic gradient, wide enough to cover the overwhelming majority of standing waters. Picocyanoprokaryotes abundance and their contribution to the total phytoplankton biomass, estimated as chlorophyll-a, 
was investigated in 32 deep and shallow lakes. The lake series covered a wide range of natural and man-made lakes, from high altitude clear lakes and deep, large subalpine lakes through large shallow lakes, small reservoirs and fish ponds. The results showed that at low chlorophyll-a concentration $\left(<10 \mu \mathrm{g}^{-1}\right)$ the picoplankton abundance tend to rapidly rise with increasing biomass. At higher chlorophyll-a concentration pico-cyanoprokaryotes abundance cannot be predicted at all being high or low independently from the total phytoplankton biomass (Fig. 5). The percentage contribution of picoplankton to the total phytoplankton biomass (as chlorophyll-a) showed much more predictable pattern along the trophic gradient (Fig. 6).

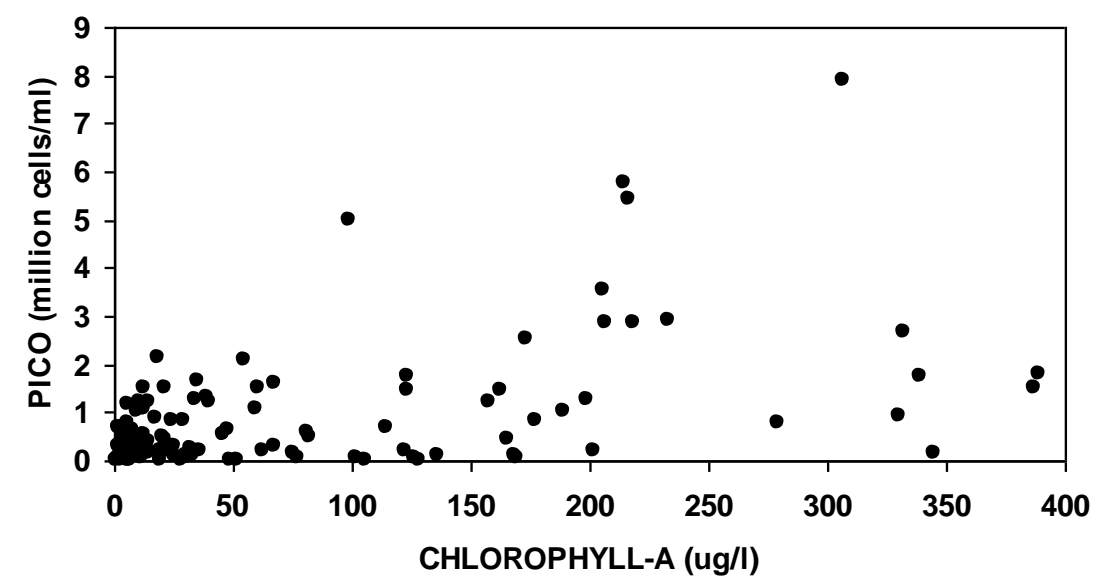

Fig. 5. Relationship between total phytoplankton biomass (chlorophyll-a) and picoplankton abundance. (Original, from Vörös 1999)

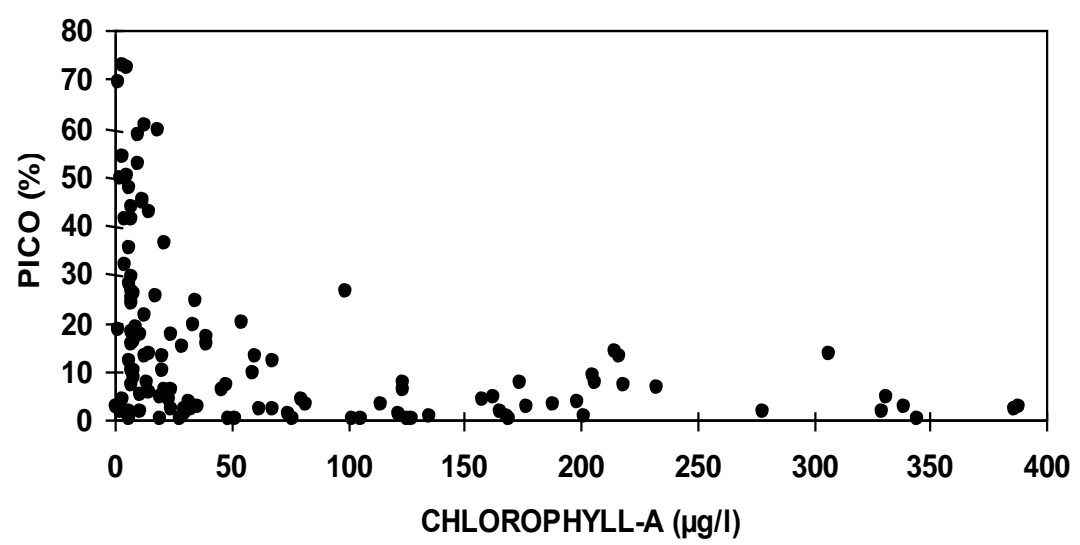

Fig. 6 Percentage contribution of picoplankton to the total phytoplankton biomass as a function of chlorophyll-a concentration. (Original, from Vörös 1999). 
An interesting investigation on the seasonal variations of size fractionated phytoplankton along the salinity gradient in York and Pamunkey Rivers estuary, Virginia, USA, Sin et al. (2000) showed the correlation's between salinity, temperature, some nutrients and different size of phytoplankton according to chlorophyll fractionation. Three stations represent the tidal fresh (Station I), riverestuary transition (Station II) and mesohaline zones (Station III) were investigated. The result of the study is summarised in Fig. 7 and Table1. The contribution of picophytoplankton to total chlorophyll a concentrations negatively correlated with total Chlorophyll-a and abundance of small cells increase as total chlorophyll-a decrease in freshwater (Chisholm, 1992; Sin et al., 2000). Degrees of mixing and turbidity are high by the river discharge rate in the river estuary transition region. Thus, phytoplankton growth in this section is likely limited by light during the cold season. Whereas small sized phytoplankton may prefer ammonium and greater light availability occurring downstream, larger cells are favored by the relatively higher nitrate concentration and lower light availability upstream (Laws, 1975). Malone (1980); Sin et al. (2000) reported that nano and pico- sized phytoplankton increase down estuary during summer and dominance of large cells increased down-estuary during winter.

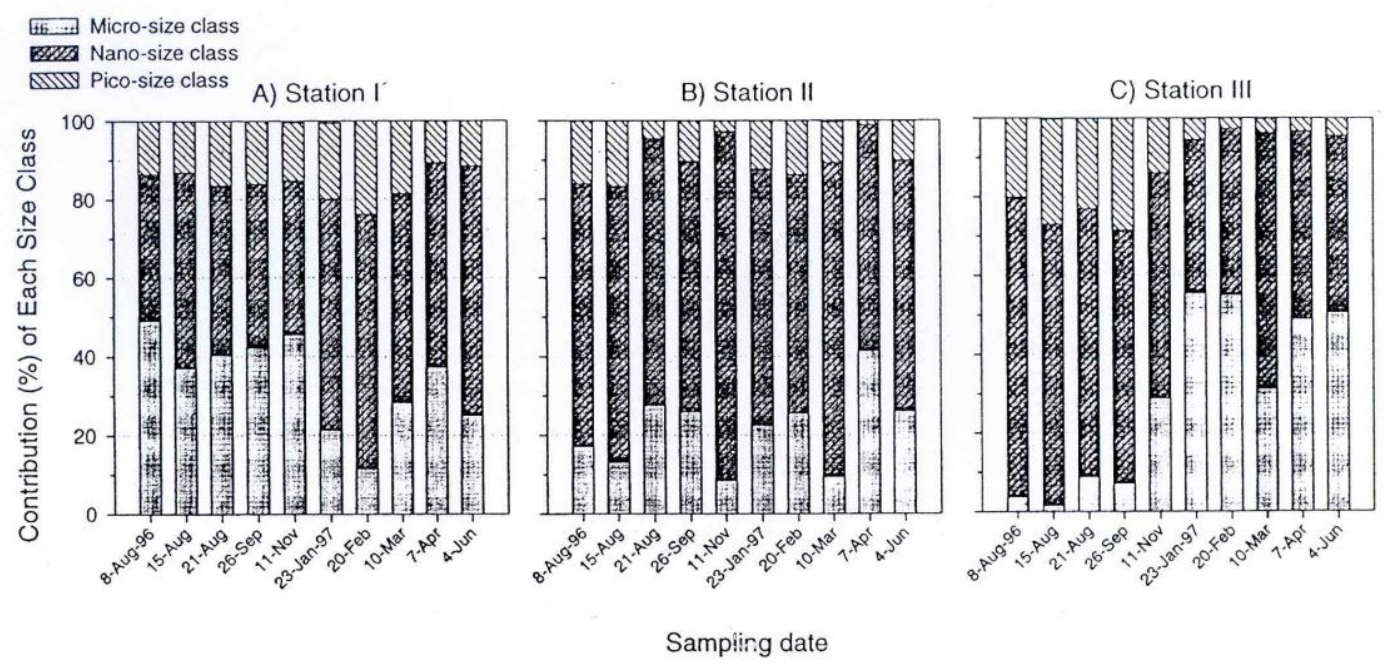

Fig. 7 Percentage contributions of three size classes (micro, nano and pico) to total chlorophyll a in the surface water of the study sites of the York River estuary. (Original, from Sin et al., 2000) 
Bell and Kalff (2001) suggested that the importance of PPP is not only a function of trophic status but also linked to water column depth in freshwater. An evaluation of the literature indicates that depth plays a complementary role to trophic status in determining the size distribution of phytoplankton communities. It dose so by affecting the resuspendion and recruitment of meroplankton from sediments and the littoral zone vegetation, as well as by affecting the microplankton loss rates through sedimentation from the mixed layer. In conclusion the abundance and contribution of pico sized plankton are a complex correlation between nitrogen form and source, light, temperature, depth and salinity.

Table 1 Results $\left(r^{2}\right)$ of liner regression analysis of surface chlorophyll a $\left(\mu \mathrm{g} \mathrm{l}^{-1}\right)$ or percentage contribution by each size class $(\%)$ versus river discharge rates $\left(\mathrm{Q}, \mathrm{m}^{3} \mathrm{~s}^{-1}\right)$, chlorophll:pheophytin ratio (Chl:Pheo), PAR at $1 \mathrm{~m}$ water depth (PAR $\mu$ Ein. $\mathrm{m}^{-2} \mathrm{~s}^{-1}$ ) and temperature $\left(\mathrm{T},{ }^{\circ} \mathrm{C}\right.$ ) during the sampling period (Fig. 5). R2 values less than 0.1 were omitted and denoted by '-', Negative value represents negative relationship

(Modified, after Sin et al., 2000).

\begin{tabular}{|c|c|c|c|c|c|c|c|c|c|c|c|c|}
\hline \multirow{2}{*}{$\begin{array}{l}\text { Size } \\
\text { class }\end{array}$} & \multicolumn{4}{|c|}{ Station I } & \multicolumn{4}{|c|}{ Station II } & \multicolumn{4}{|c|}{ Station III } \\
\hline & Q & $\begin{array}{c}\text { Chl:Ph } \\
\text { eo }\end{array}$ & PAR & $\mathrm{T}$ & Q & $\begin{array}{c}\text { Chl:P } \\
\text { heo }\end{array}$ & PAR & $\mathrm{T}$ & $Q^{*}$ & $\begin{array}{l}\text { Chl: } \\
\text { Pheo }\end{array}$ & $\begin{array}{c}\mathrm{PA} \\
\mathrm{R}\end{array}$ & $\mathrm{T}$ \\
\hline $\begin{array}{c}\text { Whol } \\
\text { e }\end{array}$ & $\begin{array}{c}- \\
0.52 \\
* *\end{array}$ & - & $\underset{*}{0 . .54^{*}}$ & $0.86^{* *}$ & 0.12 & $0.46^{* *}$ & - & 0.12 & - & - & $\begin{array}{c}- \\
0.19\end{array}$ & 0.12 \\
\hline Micro & $\begin{array}{c}- \\
0.36 \\
*\end{array}$ & -0.15 & $\underset{*}{0.58^{*}}$ & $0.81^{* *}$ & - & - & - & - & $0.58^{* *}$ & 0.19 & - & $0.69^{* *}$ \\
\hline Nano & $\underset{* *}{-}$ & - & $0.36^{*}$ & $0.68^{* *}$ & 0.10 & $0.74^{* *}$ & - & 0.10 & - & - & 0.14 & - \\
\hline Pico & $\begin{array}{c}- \\
0.37 \\
*\end{array}$ & - & $\underset{*}{0.58^{*}}$ & $0.84^{* *}$ & 0.26 & 0.28 & $0.73^{* *}$ & $0.61^{* *}$ & $-0.48^{* *}$ & 0.16 & - & $0.66^{* *}$ \\
\hline
\end{tabular}

Whole, Micro, Nano, and Pico: total, micro-sized, nano-sized and pico-sized chlorophll a

One month-lag time considered. ${ }^{* *} P<0.05,{ }^{*} P<0.1$ 
A global view of the distribution and abundance of picophytoplankton is new emerged (Partensky et al., 1999a). Prochlorococcus is the most abundant in oceanic water, coastal areas and lagoons (Vaulot et al., 1990; Partensky et al., 1999b). Vörös, in 1995, started regular investigation on picoplankton in central European lakes. Vörös in his review 1999 tried to summarise the main results of these researches, to demonstrate the significance of picoplankton in different natural and man-made lakes from oligotrophy to hyper-eutrophy. Work on the large and deep lake (Lake Constance, Austria, Germany, Switzerland), Schweizer (1997) reported that approximately 50\% of micro-and nano-plankton species identified in the open water were primarily phytobenthic species from the littoral zone and they contribute about $35 \%$ of the open water community biomass.

\section{The contribution of picophytoplankton in marine and freshwater systems}

The picophytoplankton $(<2 \mu \mathrm{m})$ contribute between 10 (Raven 1998) and 39\% (Agawin et al., 2000) to global aquatic net primary production. The wealth of data on picoplankton abundance and production in the sea has led to the conclusion that these organisms play a much greater role in oligotrophic waters (Li, 1998). Their tiny size confers small-size cells an advantage in oligotrophic waters by leading to a greater capacity to acquire nutrients and the efficiency in their use to growth and maintenance. This phenomenon became conformed in competition experiments (Shafik, 1996; 2002). From articles that contained data on total phytoplankton and picophytoplankton used chlorophyll-a as the measure of biomass, data were extracted from more than 90 studies on marine and freshwaters. The abundance, biomass and production of PPP in marine systems increase with trophic status (total Chl-a). In freshwater (Fig. 8, Table 2), although there is relationship has been previously quantified regionally but has not been evaluated for such a large number of lakes or over such a large biomass range. Although, there is no relationship between PPP abundance and total chlorophyll-a in marine waters (Table 2). The regression model including both marine and freshwater data is a considerably better fit than when is marine data used alone (Table 2). The PPP biomass increase with increasing community biomass in both freshwaters and marine waters (Fig. 9). The PPP biomass in freshwater is betwee1.5 and 3.4 times higher than in marine environments (Bell and Kalff, 2001). 
Table 2 Summary of the relationships between measures of absolute relative (\%) PPP abundance (abund; cells $\mathrm{m}^{-1}$ ), biomass $\left(\mathrm{Chl}-\mathrm{a} ; \mu \mathrm{g} \mathrm{l^{-1 }}\right.$ ), and primary production (prod; $\mu \mathrm{g} \mathrm{C}^{-1} \mathrm{~d}^{-1}$ ), and measures of total algal biomass (TChl a; $\mu \mathrm{g} \mathrm{l}^{-1}$ ) for marine

(M) and freshwater (F). SE is the stander error and $F$ is the $F$-statistic of the model. (Modified, after Bell and Kalff 2001).

\begin{tabular}{|c|c|c|c|c|c|c|c|}
\hline Fig. No. & F or $M$ & Model & $r^{2}$ & $\mathrm{n}$ & SE & $F$ & $p$ \\
\hline 5 & F & $\begin{array}{c}\log _{10}(\mathrm{PPP} \text { abund })=4.16+0.74 \log _{10} \\
(\mathrm{TChl} \mathrm{a})\end{array}$ & 0.25 & 137 & 1.02 & 44.1 & $\begin{array}{c}<0.000 \\
1\end{array}$ \\
\hline 5 & $\mathrm{M}$ & $\begin{array}{c}\log _{10}(\mathrm{PPP} \text { abund })=3.98+0.33 \log _{10} \\
(\mathrm{TChl} \text { a) }\end{array}$ & 0.03 & 122 & 0.96 & 3.5 & 0.051 \\
\hline 5 & $\mathrm{~F}+\mathrm{M}$ & $\begin{array}{c}\log _{10}(\mathrm{PPP} \text { abund })=4.13+0.73 \log _{10} \\
(\mathrm{TChl} \mathrm{a})\end{array}$ & 0.34 & 259 & 1.01 & 131.4 & $\begin{array}{c}<0.000 \\
1\end{array}$ \\
\hline 6 & F & $\begin{array}{c}\log _{10}(\text { PPP Chl a })=-0.43+0.47 \\
\log _{10}(\mathrm{TChl} a)\end{array}$ & 0.31 & 178 & 0.54 & 77.7 & $\begin{array}{c}<0.000 \\
1\end{array}$ \\
\hline 6 & M & $\begin{array}{c}\log _{10}(\text { PPP Chl a })=-0.60+0.46 \\
\log _{10}(\text { TChl a })\end{array}$ & 0.27 & 524 & 0.34 & 194.1 & $\begin{array}{c}<0.000 \\
1\end{array}$ \\
\hline 7 & M & $\begin{array}{c}\log _{10}(\text { PPP prod })=0.86+0.39 \log _{10} \\
(\text { TChl a })\end{array}$ & 0.10 & 165 & 0.54 & 14.1 & 0.0002 \\
\hline
\end{tabular}

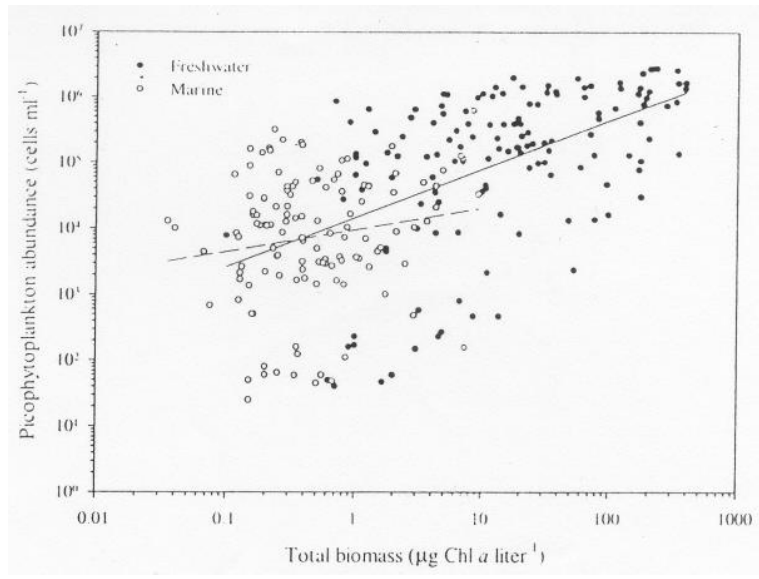

Fig. 8 Relationship between picophytoplankton abundance (cell $\mathrm{ml}^{-1}$ ) and total phytoplankton biomass ( $\mu \mathrm{g} \mathrm{Chl-a} 1^{-1}$ ). The solid line is the regression line for freshwater data, and the dashed line is the marine data. (Original, from Fig. 1 Bell and Kalff 2001). 


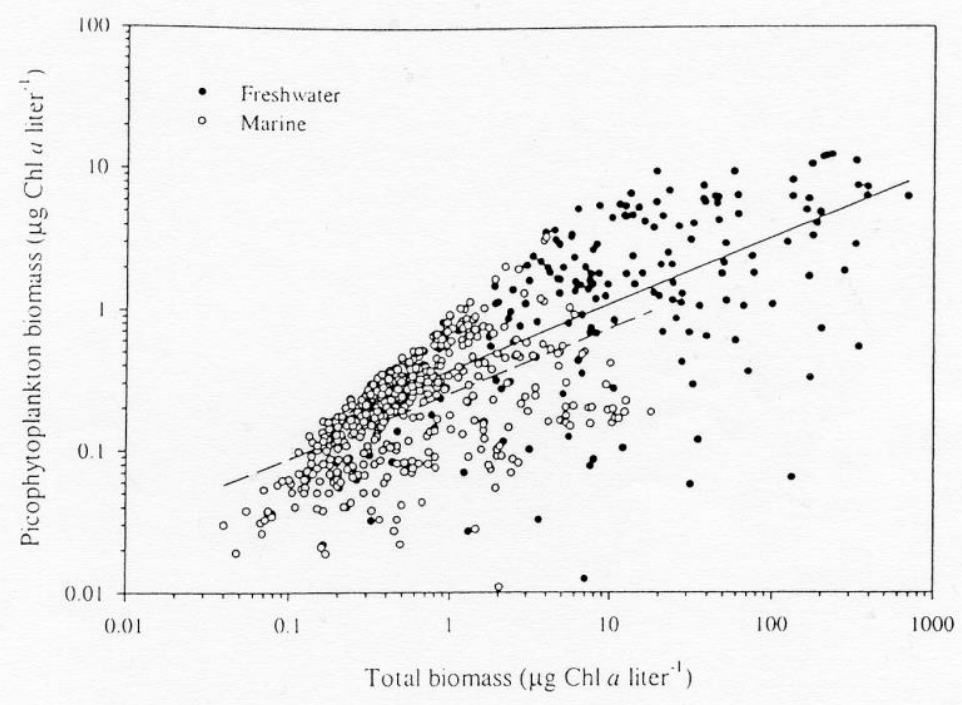

Fig. 9 Relationship between picophytoplankton biomass and total phytoplankton biomass (both in $\mu \mathrm{g} \mathrm{Chl-a}{ }^{-1}$ ). The solid line is the regression line for freshwater data, and the dashed line is the marine data. (Original from Fig. 2 Bell and Kalff 2001).

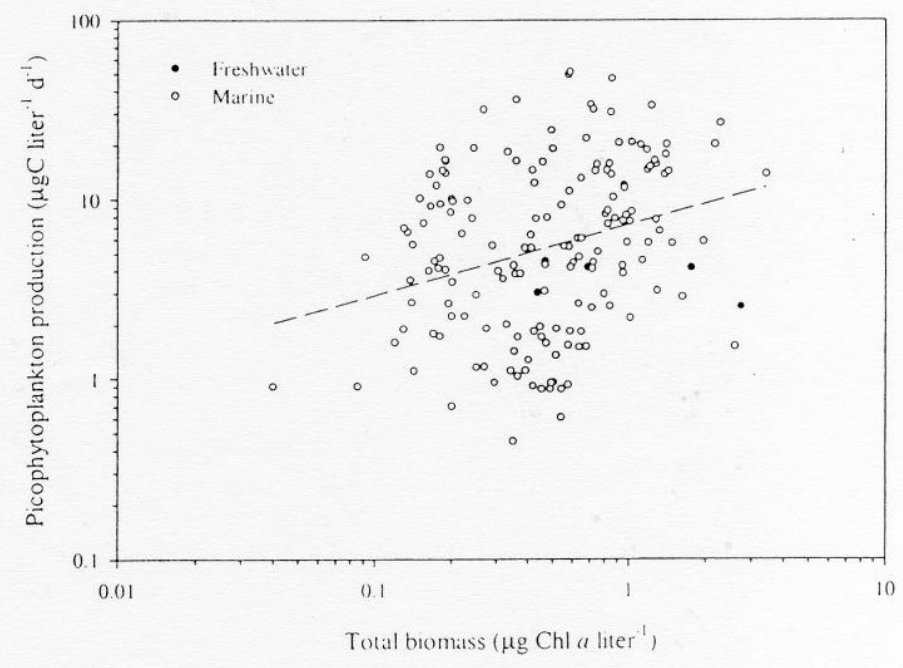

Fig. 10 Relationship between picophytoplankton production $\left(\mu \mathrm{g} \mathrm{Cl}^{-1} \mathrm{~d}^{-1}\right)$ and total phytoplankton biomass (both in $\mu \mathrm{g} \mathrm{Chl-a}{ }^{-1}$ ). The dashed line is for the marine data only. (Original from Fig. 3 Bell and Kalff 2001). 
The abundant marine data indicate that PPP production (Fig. 10) increases more slowly with increases in trophic status than dose the PPP biomass (Fig. 9). The data can not resolve whether the progressively slower increase in PPP production reflects a decreasing PPP loss rate in more productive waters or is an artifact of the methods used for separating the phytoplankton size fractions. Although the community biomass measured (Chl-a) is a useful indicator of the relative and absolute contribution of the PPP to the biomass, there is much unexplained variation, some of which is probably attributable to variable perdition and other losses suffered by the PPP and to temporal and spatial variation in sedimentation and resuspension of microplankton. Even so, it is evident that the absolute and relative contribution of the PPP to the phytoplankton biomass is consistently higher in freshwater (Bell and Kalff, 2001). Agawin et al. (2000) reported that both temperature and nutrients are statically significantly related to the contribution of picophytoplankton to total phytoplankton in compiled data set, but their effects cannot be statistically separated. However, there is evidence that the robust observed in nature is derived from the combined effect of these two factors. Li (1998) suggested that the food chain of temperate waters must shift seasonally from a dominance of larger phytoplankton cells in winter to a dominance of PPP in summer, consistent with existing reports for the NW Mediterranean (Mura $\boldsymbol{e t}$ al., 1996). The same pattern is shown in Bardawil Lagoon, Egypt (Shafik personal communication).

Malone et al. (1983) noted a large contribution of wind resuspended microplankton, mainly diatom, to the phytoplankton biomass and its variability in a marine coastal water zone. The relative importance of piocphytoplankton and nanophytoplankton could be expected to be greatest following the sedimentation of the denser microplankton during periods of low turbulence. This was demonstrated to be the case in shallow lakes, where the picophytoplankton contribute about 35\% and 50-60\% in Lake Apopka and Balaton Lake, respectively (Schelske et al., 1995; Vörös, 1999). Large phytoplanktons often dominate the phytoplankton community in temperate coastal areas during the winter and spring but decline in importance during the summer; their contribution was reduced to 1\%. A water sample from the outlet of the Aswan High Dam Lake in March 1998 shows that the abundance of picocyanobacteria was 100000 cells $\mathrm{ml}^{-1}$. Accordingly the estimation of their contribution to the total phytoplanktonic chlorophyll-a was approximately 50\% (Shafik and El-Otify, personal communication). 


\section{Seasonal dynamics of picoplankton}

In the largest central European lake (Lake Balaton) seasonal changes of the abundance and pigment composition of picoplankton together with the larger size group of the plankton were measured (Vörös et al., 1991). In the strongly eutrophicated western basin of this long shaped lake the quantity of picoplankton was the lowest in the winter months while along with rising water temperature their numbers increased until May. In summer (in spite of the highest water temperature: $24-26{ }^{\circ} \mathrm{C}$ ) picoplankton abundance was significantly reduced, but increased again in September, in spite of the falling water temperature until the latter dropped below $5-6{ }^{\circ} \mathrm{C}$. The most likely reason of the decline of picoplankton growing in summer is that these single celled cyanobacteria are widely thought to be unable to fix atmospheric nitrogen under aerobic condition and the phytoplankton of this lake was nitrogen limited in summer (Présing et al., 1996, 1999). Mass development of filamentous nitrogen-fixing filamentous cyanobacteria in the western basin of Lake Balaton was a common phenomenon during summer and their biomass changed inversely with that of picoplankton (Vörös et al., 1991). In the mesotrophic eastern basin of Lake Balaton the seasonal dynamics of picoplankton also showed marked temperature dependence without summer decline due to the less extensive nitrogen limitation than in the hypertophic lake area. The temperature dependence of the seasonal dynamics of picoplankton is well known phenomenon in the marine environment and also in deep lakes (Caron et al., 1985; Waterbury et al., 1986). Nevertheless, the upper limit of their growth is eventually set by the inorganic nutrient supply. In case of satisfactory nutrient supply picoalgae may grow in excess of the filamentous forms and can dominate in the summer phytoplankton community of highly eutrophic lakes (Bailey-Watts, 1978; Cronberg and Weibull, 1981).

\section{Light quality and picocyanoplankton}

In most lakes coccoid cyanobacteria of Synechococcus type may constitute the greatest part of the picoplankton size fraction due to their wide tolerance to light, temperature and nutrient conditions. They can be divided two groups:

Yellow autofluorescencing phycoerythrin (PE) rich cells and Red autofluorescencing phycocyanin (PC) rich cells.

Unicellular picocyanoprokaryotes strains were isolated from Lake Maggiore (Italy) and from Lake Balaton (Hungary). The strain of PE cells isolated from the euphotic zone of the deep-stratified, oligo-mesotrophic Lake Maggiore while strain of PC cells was isolated from the hyper-eutrophic western basin of the shallow Lake Balaton. Callieri et al. (1996) evaluated the effect of light quality in this two cultures under the same light intensity (blue, green, red) filtered through three coloured filters to simulate an environment with one wavelength 
predominating over the others. The PE and PC cell cultures exposed at the same light intensity but on different wavelengths.

The obtained results clearly demonstrated that the light quality had great significance in the growth regulation of the different picocyanoprokaryotes strains. The red light has the more selective importance, stimulating the PC cells to rapid growth and inducing a lower growth rate of PE cells, the growth rate of the latter was highest in case of predominance of green light. It seems the dominance of a specific wavelength has an important influence on the presence of cyanoprokaryot types in lakes. In Lake Maggiore and Lake Balaton two very different underwater light climate and picoplankton pigment composition were obtained. In the deep oligo-mesotrophic stratified Lake Maggiore, green radiation and PE cells are dominant while in the shallow hyper-eutrophic Lake Balaton the prevailing underwater radiation is red with predominance of PC cells. The laboratory experiments on the effect of the light quality on PE and PC cells support the field results and demonstrate that red light has selective function on PE cells, inducing lower growth while stimulating that of the PC cells. Green light on the other hand favours the PE cells and encourages their growth (Callieri $\boldsymbol{e t}$ al., 1996).

High amount of dissolved humic substances and/or mineral particles in the water can create similar circumstances as the high phytoplankton biomass, resulting the predominance of the red part of the underwater light spectra (V.Balogh, 1999; V.-Balogh et al., 2000). According to the parallel measurements of the underwater light climate and the composition of planktonic picocyanopropkaryotes it could determine three natural groups of the studied waters:

I- The order of light penetration is green $>$ blue $>$ red.

In these clean, oligotrophic waters vertical attenuation coefficient $\left(K_{d}\right)$ of the visible light is quite low, ranged between 0,17 and 0,40 $\left(\operatorname{ln~m}^{-1}\right)$. Here PE rich cyanobacteria dominate.

II. The order of light penetration is green $>$ red $>$ blue

In these lakes vertical attenuation coefficient $\left(K_{d}\right)$ of the visible light is ranged between 0,41 and 2,0 $\left(\operatorname{ln~m}^{-1}\right)$. In these, mainly moderately eutrophicated lakes the coexistence of PE and PC cells is characteristic phenomenon.

III. The order of light penetration is red $>$ green $>$ blue

In these lakes vertical attenuation coefficient $\left(K_{d}\right)$ of the visible light is higher than 2,0 $\left(\mathrm{ln} \mathrm{m}^{-1}\right)$. In these eutrophic and/or humic or suspended solid rich lakes the absolute dominance of PC cells is characteristic phenomenon. For more details see V.-Balogh et al. (2000). 


\section{Effect of $U V B$ radiation on picoplankton:}

There are small amount of data available in the literature on the effects of UVB on picoplankton cells show that, as for other algal groups, UVB inhibits the photosystem II reaction center activity, altering the structure of D1/D2 polypeptides and the light-harvesting complex (Rajagopal and Murthy, 1996). Bergeron and Vincent (1997) have found a significant decrease of PPP and not of bacterioplankton in presence of UVB in arctic lake. Herndl et al. (1993) demonstrated that UVB solar radiation can inhibit bacterial activity by as much $40 \%$. Bertoni and Callieri (1999) reported that there is no inhibition effect of UVB on the activities of PPP and algal cells $>2 \mu \mathrm{m}$. Experiments on artificial UVB shows that the PPP and bacterioplankton inhibit with increasing the radiation energy values from natural level to $-10 \mu \mathrm{w} \mathrm{cm}$ (at $305 \mathrm{~nm}$ ). PPP could be less affected than bacteria by UVB irradiation because they can promptly synthesize MAAs or other photoprotective substances (Carreto et al., 1990). The effect of wavelengths longer than UV are more strong on growth rate and photosynthetic efficiency of natural phytoplankton population than UVB (Bertoni and Callieri, 1999). The effect of longer wavelengths is indirect and must, therefore, be regarded with caution.

\section{Using of 18S rDNA sequences and phylogenic analysis for study of picophytoplankton}

Direct probing and sequencing of genetic material from marine sample has led to discoveries of novel lineages in Bacteria and Archaea (Pace, 1997) and has demonstrated that sole reliance on cultured organisms was providing a somewhat biased view of oceanic diversity. The same appears to be true for eukaryotic plankton. It is clear that once molecular analyses have revealed new lineages, it is critical to identify and bring into cultures the corresponding organisms. In this perspective, $18 \mathrm{~S}$ rRNA probes designed from environmental sequences should be very useful tools to visualise (for example by fluorescent in situ hybridisation) target cells in field samples to determine their morphology or in enrichment cultures to optimise culture conditions favoring them. See below for sequencing and phylogenetic analysis method.

In summery, Only two $18 \mathrm{~S}$ rDNA sequences were closely affiliated with known prymnesiophyte sequences (Fig. 11). Clone OLI16108 grouped with $C$. leadbeateri, with $96.7 \%$ sequence similarity. Clone OLI51004, which perfectly matched the PHAEO01 probe at the target site, grouped with P. globosa, with $99.3 \%$ sequence similarity. 


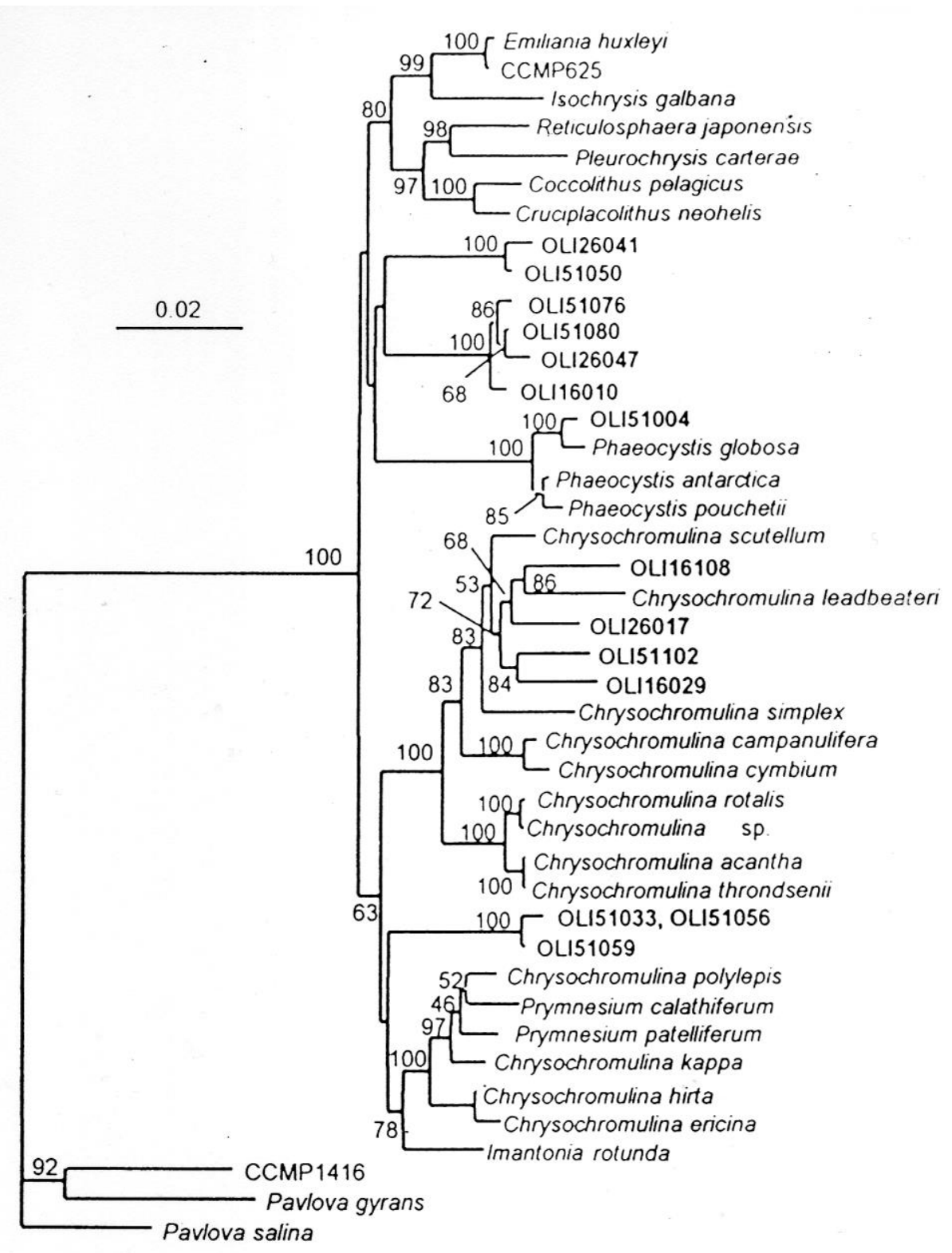

Fig. 11 Phylogenetic relationship (neighbor-joining) among prymnesiophytes. Palvova salina was used as outgroup. Numbers at nodes represent the bootstrap percentage from 100 replicates. Values below $50 \%$ are not shown. The scale bar indicates substitutions per nucleotide position. (Original, from Fig 2 Moon van der Staay et al., 2000) 
Clones OLI26017, OLI16108, OLI51102, and OLI16029 were included in the Chrysochromulina clade. The lineage comprising clones OLI 51033, OLI51056 and OLI51059 showed a weakly supported sister-group relationship with the clade that includes some species of Chrysochromulina (C. hirta, C. ericina, C. kappa, C. polylepis) and the genus Prymnesium (Fig. 11). Two environmental lineages represented by six clones (OLI51050, OLI26041, OLI51080, OLI51076, OLI16010, OLI26047) appeared to be affiliated with the coccolithophorids (Emiliania, Pleurochrysis, Coccolithus, Cruciplacolithus), Isochrysis, Reticulopsphaera, and Phaeocystis rather than with the Prymnesiales (Fig. 11). However, this relationship was not strongly supported by bootstrap values. See Moon van der Staay et al. (2000) for more details.

\section{Importance of picoplankton in the primary production}

In the hypertrophic area of Lake Balaton, according to the regular fractionated ${ }^{14} \mathrm{C}$-measurements (Vörös, 1991) picoplankton contribution to the total planktonic primary production was substantial $(57 \%)$ in springtime. When the abundance of nitrogen fixing blue-greens increased in summer their contribution was reduced to $1 \%$. In fall, along with the reduction of the activity of nitrogen fixing algae their contribution increased again. As opposed to the above mentioned situation the picoplankton contribution to planktonic primary production was fairly uniform in the meso-eutrophic area, about $50 \%$. In a strongly eutrophicated small reservoir (Marcali reservoir, surface area: $4 \mathrm{~km}^{2}$ ) due to the absence of nitrogen fixing algae (Présing et al., 1997) and filter feeding zooplankton the contribution of picoplankton to the total planktonic primary production was steadily increasing between April and August and reached $50 \%$ summer peak. According to the literature apparently the general situation is that the contribution of picoplankton to the total planktonic primary production decreases with the increasing trophic level, however there were exceptions of this overall tendency (Stockner, 1988). Vörös $(1991,1999)$ indicated that picoplankton may significantly contribute (50$60 \%)$ to the photosynthetic activity of phytoplankton even in extremely productive water bodies, if their activity was not restricted by some specific conditions (nitrogen limitation, zooplankton grazing etc.).

\section{Effect of zooplankton grazing on picoplankton abundance}

In the summer of 1987 the effect of plant nutrient loads on the mass, composition and photosynthetic activity of phytoplankton was measured in the hyper-eutrophic western basin of Lake Balaton in the limnocorral (enclosure) experiments, maintaining differing nutrient supply and suspended solid concentrations (Vörös et al., 1991). In the shallow Lake Balaton zooplankton growth is being mostly 
limited by suspended mineral particles scoured by wave motion (G.-Tóth $\boldsymbol{e t}$ al., 1986). In these enclosures water was calmer than in the surrounding open water, resulting in a reduced concentration of suspended solids, and this facilitated the rapid growth of filter feeding crustacean plankton (Daphnia species, Diaphanosoma brachiurum). As opposed to the suspended solid concentration of $4-8 \mathrm{mg} \mathrm{l}^{-1}$ in the limnocorrals its concentration in the open water (20-40 $\mathrm{mg} \mathrm{l}^{-1}$ ) affected zooplankton growth, resulting in relatively stable concentration of the latter during the experiments. In these enclosures the growth and feeding of Cladocera had dramatic impact on the picoplankton population. Due to the intensive grazing, picoplankton totally disappeared from these limnocorrals within few days. The suspended solid concentration was kept at the natural level, by adding and mixing solids artificially. The conditions created this way restricted zooplankton growth significantly and thus the picoplankton concentration was not reduced to the level of the other enclosures, but stayed at that of the open water, where the picoplankton abundance was permanently high and Cladocera could not growth. Experiments carried out in limnocorrals showed that zooplankton may exercise considerably control on picoplankton when conditions are favourable for the growth of herbivorous zooplankton. Some deep lakes create more favourable conditions for planktonic Cladocera than shallower water bodies where sediment is often stirred up by wind induced wave motion.

\section{Effect of filter feeding fishes on picoplankton}

Marcali reservoir (Hungry) was built on the catchment area of Lake Balaton to reduce the mineral nutrient load of the lake. It was filled and emptied biennially. At the beginning of these cycles, the reservoir was heavily stocked with filter feeding fishes. About $80 \%$ of the stocked and harvested fish population was silver carp (Hypophthalmichtys molitrix Val.), 15\% bighead carp (Aristichthys nobilis Rich.) and only $5 \%$ common carp (Cyprinus carpio L.). In the different farming cycles the introduced fish biomass altered between 500 and $1800 \mathrm{~kg} \mathrm{ha}^{-1}$ but the net fish production showed little variation with an average of $500 \mathrm{~kg} \mathrm{ha}^{-1}$ year (Vörös et al., 1998b). The food ingestion and the feeding selectivity of silver carp are a mechanical, passive function of its filter morphology. Distances between the silver carp's gill rakers range from 12 to $26 \mu \mathrm{m}$, which is consistent with experimental results that the lower limit for available food particles is about 10 $\mu \mathrm{m}$. A logical consequence of this circumstance is that silver carp grazing can not control total phytoplankton biomass, but will modify the size structure of algal communities.

Comparison of the composition of natural phytoplankton communities with the gut content of silver carp (Vörös et al., 1997) showed that this fish species could not take up algae smaller than $10 \mu \mathrm{m}$. Species composition of algal assemblages in the gut content of silver carp usually differs significantly from the 
composition of the $>10 \mu \mathrm{m}$ size fraction of the natural phytoplankton communities. This difference is mainly a result of the taxon selective digestion of silver carp. In vitro experiments with digestive enzymes of this species resulted in very fast (1-2 minutes) disintegration of non-mucilaginous cyanoprokaryotes. Digestion of diatoms and cryptophytes was also effective, but mucilaginous cyanobacteria and green algae (Chlorococcales) proved practically indigestible. According to the above mentioned measurements, in the case of silver carp the planktonic algae can be divided into there groups that cross the taxonomical lines (Vörös et al., 1997):

1. Non available algae $(<10 \mu \mathrm{m})$ : autotrophic picoplankton, small cryptophytes, small centric diatoms and several Chlorococcales green algae were the dominant members of this group.

2. Available $(>10 \mu \mathrm{m})$ but non-digestible algae: the most common Chlorococcales green algae belonged to this group. Besides the Scenedesmus, Tetraedron, Tetrastrum, Pediastrum, Oocystis, Coelastrum, Chodatella etc. species some mucilagenous Chroococcales-type cyanobacteria and Euglenophyta were not easily digested.

3. Available $(>10 \mu \mathrm{m})$ and digestible algae: inside this size category, nonmucilaginous filamentous cyanobacteria (Aphanizomenon flos-aquae, Cylindrospermopsis raciborskii etc.), Cryptomonas species and diatoms proved to be well digestible.

These results suggest that the silver carp grazing have a complex effect on the phytoplankton structure. The size selective filtration can effectively control the large sized digestible algae, including bloom-forming cyanoprokaryotes. Accordingly, the growth of small-sized phytoplankton (including pico-sized algae) is significantly enhanced in the presence of silver carp because the size selective filtration of this species controls their large sized algal competitors and grazers (zooplankton).

\section{Conclusion}

I suggest that analyses of phytoplankton size structure are necessary to better understand controls on phytoplankton dynamics and to better manage water quality in different aquatic systems. The estimation of picocyanoprokaryotes contribution to the total phytoplanktonic chlorophyll-a was approximately $50 \%$ in the outlet of the Aswan High Dam Lake. The abundance and contribution of pico sized plankton are a complex correlation between nutrients, nitrogen form and source, phosphorous, light, temperature, salinity, etc. 


\section{References}

Agawin, N. S. R.; Duarte, C. M. and Agusti, S. (2000). Nutrient and temperature control of the contribution of picoplankton to phytoplankton biomass and production Limnol. Oceanogr., 45: 591-600

Ambrožová, J. (2001). Separation methods for the concentration of picoplankton. Algol. Stud., 137: 129-135.

Andersen, R. A.; Saunders, G. W.; Paskind, M. P. and Sexton, J. P. (1993). Ultrastructure and 18S rRNA gene sequence for Pelagomonas calceolata gen. et sp. nov. and the description of a new algal class, the Pelagophyceae classis nov. J. Phycol., 29: 701-715.

Bailey-Watts, A. E. (1978). A nine-year study of the phytoplankton of the eutrophic and non-stratifying Loch Leven (Kinross, Scotland). J. Ecol., 66: 741-771.

Bell, T. and Kalff, J. (2001). The contribution of picophytoplankton in marine and freshwater systems of different trophic status and depth. Limnol. Oceanogr., 46: 1243-1248.

Bergeron, M. and Vincent, W. F. (1997). Microbial food web responses to phosphorus supply and solar UV radiation in a subarctic lake. Aquat. Microb. Ecol., 12: 239-249.

Bertoni, R. and Callieri, C. (1999). Effects of UVB radiation on freshwater autotrophic and heterotrophic picoplankton in a subalpine lake. $J$. Plankton Res., 21: 1373-1388.

Cavender-Bares, K. K.; Mann, E. L.; Chisholm, S. W.; Ondrusek, M. E. and Bidigare, R. R. (1999). Differential response of equatorial Pacific phytoplankton to iron fertilization .Limnol. Oceanogr., 44: 237-246.

Callieri, C.; Amicucci, E.; Bertoni R. and Vörös, L. (1996). Fluorometric characterization of two picocyanobacteria strains from lakes of different underwater light quality. Internat. Revue. ges. Hydrobiol., 81: 13-23.

Caron, D. A.; Be, A. W. H. and Anderson, O. R. (1982). Effects of variations in light intensity on life processes of the planktonic foraminifer Globigerinoides sacculifer in laboratory culture. J. Mar. Biol. Assoc. U.K., 62: 435-451

Caron, D. A.; Pick, F. R. and Lean, D. R. S. (1985). Chroococcoid cyanobacteria in Lake Ontario: seasonal and vertical distribution during 1982. J. Phycol., 21: 171-175

Caroppo, C. (2000). The contribution of picophytoplankton to community structure in a Mediterranean brackish environment. J. Plankton Res., 22: 381-397 
Carreto, J. I.; Carignan, M. O.; Daleo, G. and De Marco, S. G. (1990). Occurrence of mycosporine-like amino acids in the red-tide dinoflagellate Alexandrium excavatum : UV-photoprotective compounds? J. Plankton Res., 12: 909-921.

Chisholm, S. W.; Olson, R. J.; Zettler, E. R.; Goerick, R.; Waterbury, J. B. and Welschmeyer, N. A. (1988). A novel free-living prochlorophyte abundant in the oceanic euphotic zone. Nature, 334: (6180), 340-343.

Chisholm, S. W. (1992). What limits phytoplankton growth?. Oceanus, 35: 36-46.

Chisholm, S. W.; Frankel, S. L.; Goericke, R.; Olson, R. J.; Palenik, B.; Waterbury, J. B.; West-Johnsrud, L. and Zettler, E. R. (1992). Prochlorococcus marinus nov. gen. nov. sp.: An oxyphototrophic marine prokaryote containing divinyl chlorophyll a and b. Arch. Microbiol., 157: 297-300.

Cronberg, G. and Weibull, C. (1981). Cyanodictyon imperfectum a new chroococcal blue-green alga from Lake Trummen, Sweden. Arch. Hydrobiol. Suppl., 60:101-110.

Collier, J. L. (2000). Flow cytometry and the single cell in phycology. $J$. Phycol., 36: 628-644.

Crosbie, N. D. and Furnas, M. J. (2001). Abundance, distribution and flow-cytometric characterization of picophytoprokaryote populations in central (17 degree $S$ ) and southern (20 degree $S$ ) shelf waters of the Great Barrier Reef. J. Plankton Res., 23: 809-828.

DeYoe, H. R.; Chan, A. M. and Suttle, C. A. (1995). Phylogeny of Aureococcus anophagefferens and a morphologically similar bloomforming alga from Texas as determined by $18 \mathrm{~S}$ ribosomal RNA sequence analysis. J. Phycol., 31: 413-418.

Felsentein, J. (1993). PHYLIP (Phylogeny Inference Package). Version 3.5c Department of Genetics, University of Washington.

Froneman, P. W.; Laubscher, R. K. and Mcquaid, C. D. (2001). Sizefractionated Primary Production in the South Atlantic and Atlantic Sectors of the Southern Ocean. J. Plankton Res., 23: 611-622.

G.-Tóth L.; V.-Balogh, K. and P-Zánkai, N. (1986). Significance and degree of abioseston consumption in the filter-feeder Daphnia galeata Sars am. Richard (Cladocera) in Lake Balaton. Arch. Hydrobiol., 106: 45-60. 
Guillou, L; Chretiennot-Dinet, M-J.; Medlin, L. K.; Claustre, H.; Goeer, SL-D. and Vaulot D. (1999). Bolidomonas: A new genus with two species belonging to a new algal class, the Bolidophyceae (Heterokonta) J. Phycol., 35: 368-381.

Hawley, G. R. W. and Whitton, B. A. (1991). Seasonal changes in chlorophyll-containing picoplankton populations of ten lakes in northern England. Int. Rev. gesamt. Hydrobiol. Berlin., 76: 545-554.

Herndl, G. J.; Mueller-Niklas, G.and Frick, J. (1993). Major role of ultraviolet-B in controlling bacterioplankton growth in the surface layer of the ocean. Nature, 361: 717-719.

Hobbie, J. E.; Daley, R. J. and Jasper, S. (1977). Use of nuclepore filters for counting bacteria by fluorescence microscopy. Appl. Environm. Microbiol., 33: 1225-1228.

Iturriaga, R. and Marra, J. (1988). Temporal and spatial variability of chroococcoid cyanobacteria Synechococcus spp. specific growth rates and their contribution to primary production in the Sargasso Sea. Mar. ecol. Prog.ser., 44: 175-181.

Johnson, P. W. and Sieburth, J. McN. (1979). Chroococcoid cyanobacteria in the sea: a ubiquitous and diverse phototrophic biomass. Limnol. Oceanogr., 24: 928-935.

Kimura, M. (1980). A simple method for estimating evolutionary rates of base substitution through comparative studies of nucleotide sequences. J. Mol. Evol., 16: 111-120.

Laws, E. A. (1975). The importance of respiration losses in controlling the size distribution of marine phytoplankton. Ecology, 56: 419-426.

Li, W. K. W. (1998). Annual average abundance of heterotrophic bacteria and Synechococcus in surface ocean waters. Limnol. Oceanogr., 43: 1746-1753.

Lopez-Garcia, P.; Rodriguez-Valera, F.; Pedros-Allo, C. and Moreira, D. (2001). Unexpected diversity of small eukaryotes in deep-sea Antarctic plankton Nature [Nature]. Vol. 409, no. 6820, pp. 603-607.

Maildak, B. L.; Larsen, N.; McCaughey, M. J.; Overbeek, R.; Olsen, G. J.; Fogel, K.; Blandy, J. and Woese, C. R. (1994). The ribosomal database project. Nucleic Acids Res., 22: 3485-3487.

Malone, T. C. (1980). Size-fractionated primary productivity of marine phytoplankton In: Primary productivity in the sea., Publ. by: Plenum; New York, NY (USA). Environ. Sci. Res., 19: 301-319. 
Malone, T. C.; Falkowski, P. G.; Hopkins, T. S.; Rowe, G. T. and Whitledge, T. E. (1983). Mesoscale response of diatom populations to a wind event in the plume of the Hudson River. Deep-Sea Res., 30A: 149-170.

Mastala, Z; Herodek, S.; V-Balogh, K; Borbely, G; Shafik, H. M. and Vörös, L. (1996). Nutrient requirement and growth of a Synechococcus species isolated from Lake Balaton. Int. Rev. Gesamt. Hydrobiol., 81: 503-512

Moon-Van der Staay, S. Y.; van der Staay, G. W. M.; Guillou, L.; Vaulot, D.; Claustre, H. and Medlin, L. K. (2000). Abundance and diversity of prymnesiophytes in the picoplankton community from the Equatorial Pacific Ocean inferred from $18 \mathrm{~S}$ rDNA sequences. Limnol. Oceanogr., 45: 98-109.

Moon-van der Staay, S. Y.; De Wachter, R and Vaulot, D. (2001). Oceanic 18S rDNA sequences from picoplankton reveal unsuspected eukaryotic diversity. Nature, 409: 607-610.

Mura, M. P.; Agusti, S.; Giorgio, Padel., Gasol, J. M.; Vaque, D. and Duarte, C. M. (1996). Loss-controlled phytoplankton production in nutrient-poor littoral waters of the NW Mediterranean: In situ experimental evidence. MAR. ECOL. PROG. SER., 130: 213-219.

Pace, N. R. (1997). A molecular view of microbial diversity and the biosphere. Science, 276: 734-740.

Partensky, F; Hess, WR and Vaulot, D (1999a). Prochlorococcus, a marine photosynthetic prokaryote of global significance. Microbiol. Mol. Biol. Rev., 63: 106-127.

Partensky, F.; Blanchot, J. and Vaulot, D. (1999b). Differential distribution and ecology of Prochlorococcus and Synechococcus in oceanic waters: a review Marine Cyanobacteria. Bull. Inst. Oceanogr. Monaco., 19: 457-475.

Potter, D; Lajeunesse, T. C.; Saunders, G. W. and Anderson, R. A. (1997). Convergent evolution masks extensive biodiversity among marine coccoid picoplankton. Biodivers. Conserv., 6: 99-107.

Présing, M.; Herodek, S.; Vörös, L. and Karbor, I. (1996). Nitrogen fixation, ammonium and nitrate uptake during a bloom of Cylindospermopsis raciborskii in Lake Balaton. Arch. Hydrobiol., 136: 553-562.

Présing, M.; V-Balogh, K.; Vörös, L. and Shafik, H. M. (1997). Relative nitrogen deficiency without occurrence of nitrogen fixing blue-green algae in hypertrophic reservoir. Hydrobiologia, 342/343:55-61. 
Présing, M.; Herodek, S.; Vörös, L.; Preston, T. and Abrusán, Gy. (1999). Nitrogen uptake by summer phytoplankton in Lake Balaton. Arch. Hydrobiol., 145: 93-110.

Rajagopal, S. and Murthy, S. D. S. (1996). Ultraviolet-B radiation induced alterations in photosynthetic electron transport activites of the cyanobacterium Synechococcus 6301. Photosynthetica 32: 281-284.

Raven, J. A. (1998). The twelfth tansley lecture. Small is beautiful: The picophytoplankton Funct. Ecol., 12: 503-513.

Saunders, G. W.; Potter, D. and Andersen, R. A. (1997). Phylogenetic affinities of the Sarcinochrysidales and Chrysomeridales (Heterokonta) based on analyses of molecular and combined data. J. Phycol., 33: 310318.

Schelske, C. L.; Carrick, H. J. and Aldridge, F. J. (1995). Can windinduced resuspension of meroplankton affect phytoplankton dynamics? J. N. Am. Benthol. Soc., 14: 616-630.

Steitz, A and Velimirov, B (1999). Contribution of picocyanobacteria to total primary production and community respiratory losses in a backwater system. J. Plankton Res., 21: 2341-2360.

Schweizer, A. (1997). From littoral to pelagial: Comparing the distribution of phytoplankton and ciliated protozoa along a transect. J. Plankton Res., 19: 829-848.

Shafik H. M. (1996). Competition between phyto-and bacterioplankton from Lake Balaton in continuous cultures. J. Union Arab Biol. Cairo., 3 (B), 49-65.

Shafik H. M. (2002). Succession of a Freshwater phytoplankton Community in ammonium Limited Chemostat cultures Bullitan Assiut

Sieburth, J. M.; Smetacek, V. and Lenz, J. (1978). Pelagic ecosystem structure: Heterotrophic compartments of the plankton and their relationship to plankton size fractions. Limnol. Oceanogr., 23: 12561263.

Sin, Y.; Wetzel, R. L. and Anderson, I. C. (2000). Seasonal variations of size-fractionated phytoplankton along the salinity gradient in the York River estuary, Virginia (USA) J. Plankton Res., 22: 1945-1960.

Stockner, J. G. 1988 Phototrophic picoplankton: An overview from marine and freshwater ecosystems. Limnol. Oceanogr., 33: 765-775.

Stockner, J. G. and Antia, N. J. (1986). Algal picoplankton from marine and freshwater ecosystems: a multidisciplinary perspective. Can. J. Fish. Aquat. Sci., 43: 2472-2503. 
Stockner, J. G. (1991). Autotrophic picoplankton in freshwater ecosystems: The view from the summit. Int. Revue ges. Hydrobiol., 76: 483-492.

Takahashi, M.; Kikuchi, K. and Hara, Y (1985). Importance of picocyanobacteria biomass (unicellular, blue-green algae) in the phytoplankton population of the coastal waters off Japan. Mar. biol. Berlin, Heidelberg., 89: 63-69.

Thompson, J. D.; Higgins, D. G. and Gibson T. J. (1994). CLUSTAL W: Improving the sensitivity of progressive multiple sequence alignment through sequence weighting, position-specific gap penalties and weight matrix choice. Nucleic Acids Res., 22: 4673-4680

Utermöhl, H. (1958). Zur Vervollkommung der quantitativen Phytoplankton. Methodik. Mitt. Int. Ver. Limnol., 9: 1-38.

Waterbury, J. B., Watson, S. W., Guillard, R. R. and Brand, L. E. (1979). Widespread occurrence of a unicellular, marine, planktonic cyanobacterium. Nature, 277: 293-294.

Waterbury, J. B.; Watson, S. W.; Valois, F. W. and Franks, D. G. (1986). Biological characterization of the marine unicellar cyanobacterium Synechococcus. Can. Bull. Fish. Aquatic Sci., 214:71120.

Vaulot, D.; Courties, C. and Partensky, F. (1989). Heterogeneity in fragility and other biochemical and biophysical properties: A simple method to preserve oceanic phytoplankton for flow cytometric analyses. Cytometry in aquatic sciences, Cytometry, 10: 629-634.

Vaulot, D.; Partensky, F.; Neveux, J.; Mantoura, R. F. C.and Llewellyn, C. A. (1990). Winter presence of prochlorophytes in surface waters of the northwestern Mediterranean Sea. Limnol. Oceanogr., 35: 11561164.

Vaulot, D; and Marie, D (1999). Variability of photosynthetic picoplankton in the equatorial Pacific. J. Geophys. Res. (C Oceans). 104: 3297-3310.

V.-Balogh, K. (1999). Effect of humic substances on phytoplankton in lakes. In Shafik H. M. (ed.) Role of algae in development and purification of lakes and rivers. Suez Canal University Press, Egypt. 1: 49-70.

V.-Balogh, K.; Koncz, E. and Vörös, L. (2000). An empirical model describing the contribution of colour, algae and particles light climate of shallow lakes. Verh. Internat. Verein. Limnol., 27: 2678-2681.

Vörös, L. (1991). Importance of picoplankton in Hungarian shallow lakes. Verh. internat. Verein. Limnol., 24: 984-988. 
Vörös, L. (1999). Role of autotrophic picoplankton in lakes In Shafik H.M. (ed.) Role of algae in development and purification of lakes and rivers. Suez Canal University Press, Egypt. 1: 31-48.

Vörös, L. and Padisák J. (1991). Phytoplankton biomass and chlorophyll-a in some shallow lakes in central Europe. Hydrobiologia, 215: 111-119.

Vörös, L.; Gulyás, P. and Németh, J. (1991). Occurrence, dynamics and production of picoplankton in Hungarian shallow lakes. Int. Revue ges. Hydrobiol., 76: 617-629

Vörös, L.; Oldal, I.; Présing M. and V.-Balogh K. (1997). Size-selective filtration and taxon-specific digestion of plankton algae by silver carp (Hypophthalmichthys molitrix Val.). Hydrobiologia, 342/343: 223-228

Vörös, L.; Callieri, C.; V.-Balogh K. and Bertoni R. (1998a). Freshwater picocyanobacteria along a trophic gradient and light quality range. Hydrobiologia, 369/370: 117-125.

Vörös, L.; Présing, M.; V.-Balogh, K. and Oldal, I. (1998b). Nutrient removal efficiency of a pollution control reservoir. Int. Revue ges. Hydrobiol., 83: (Spec. Issue) 665-672

Vörös, L.; Balogh, K. V.; Herodek, S. and Kiss, K. T. (2000). Underwater light conditions, phytoplankton photosynthesis and bacterioplankton production in the Hungarian section of the River Danube. Arch. Hydrobiol., (Suppl.) (Large Rivers) 115: 511-532.

Yentsch, C. M.; Mague, F. C.; Horan, P. K. and Muirhead, K. (1983). Flow cytometric DNA deteminations on individual cells of the dinoflagellate Gonyaulax tamarensis var. excavata. J. Exp. Mar. Biol. Ecol., 67: 175-183.

Zettler, E. R.; Olson, R. J.; Binder, B. J.; Chisholm, S. W.; Fitzwater, S. E. and Gordon, R. M. (1996). Iron-enrichment bottle experiments in the Equatorial Pacific: Responses of individual phytoplankton cells Deep-Sea Res. (II Top. Stud. Oceanogr.) 43: 1017-1029 


$$
\begin{aligned}
& \text { دور الهوام المتتاهية في الصغر في البيئات المائية } \\
& \text { هشام محمد شفيق } 29 \text { و هلجا ليتولد } 3
\end{aligned}
$$

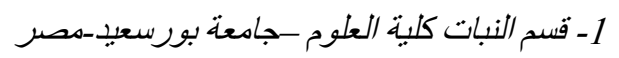

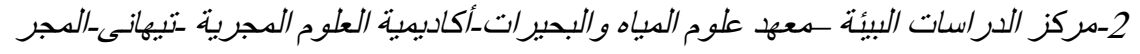

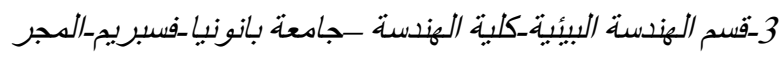

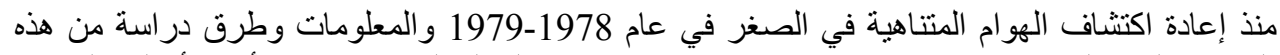

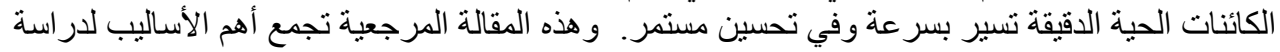

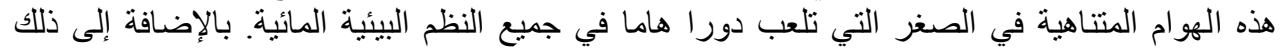

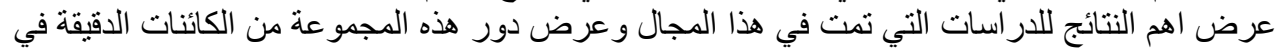

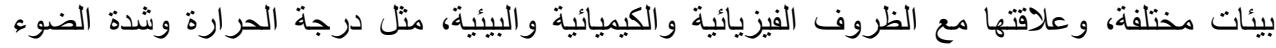

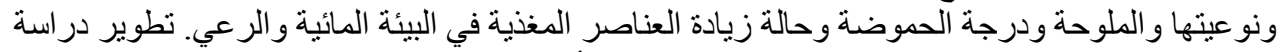

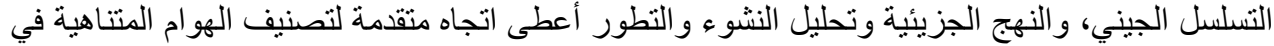

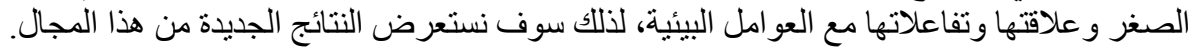

